\title{
Influence of Mild Hypothermia on Hypoxic- Ischemic Brain Damage in the Immature Rat
}

\author{
J. YAGER, J. TOWFIGHI, AND R. C. VANNUCCI \\ Department of Pediatrics [J.Y]. Royal University Hospital, Lniversity of Saskatchewan. Saskatoon. \\ Saskatchewan. Canada. S7N OXO; and Department of Pathology' (Neuropathology) |J.T.I and Pediatric Neurology' \\ [R.C.I.J. The Milton S. Hershey Medical Center. The Pennsylvania State University: \\ Hershey: Pennsylvania 17033
}

\begin{abstract}
Recent studies in adult animals have shown that even small decreases in brain or core temperature ameliorate the damage resulting from hypoxic-ischemic insults. To determine the effect of minor reductions in ambient temperature either during or after an hypoxicischemic insult on the brain of the immature rat, 7-dpostnatal rat pups underwent unilateral common carotid artery ligation followed by exposure to hypoxia in $8 \%$ oxygen for $3 \mathrm{~h}$. Control animals were maintained at $37^{\circ} \mathrm{C}$ during hypoxia-ischemia. Intraischemic hypothermia was induced during the insult at temperatures of $34^{\circ} \mathrm{C}$ and $31^{\circ} \mathrm{C}$. Postischemic hypothermia was induced by exposing rat pups that underwent hypoxia at $37^{\circ} \mathrm{C}$ to recovering environments of $34^{\circ} \mathrm{C}$ and $31^{\circ} \mathrm{C}$. Temperatures were recorded every $15 \mathrm{~min}$ from thermistor probes placed in the ipsilateral hemisphere and rectally. Neuropathologic alterations were assessed at 30 postnatal d. During hypoxia, animals became poikilothermic. Brain damage occurred in $90 \%$ of rat pups exposed to hypoxia-ischemia at $37^{\circ} \mathrm{C}$. Cerebral injury significantly decreased with decreasing temperatures during hypoxia-ischemia $(p<0.01)$. Only $30 \%$ of rats had brain damage when exposed to hypoxia-ischemia at $34^{\circ} \mathrm{C}$, and none of the rats exposed at $31^{\circ} \mathrm{C}$ had brain damage. In contrast, there was no difference in the extent of cerebral injury between rat pups recovered under hypothermic conditions of either $34^{\circ} \mathrm{C}$ or $31^{\circ} \mathrm{C}$ compared with those recovered at $37^{\circ} \mathrm{C}$. The results indicate that reductions in temperature of 3 to $6^{\circ} \mathrm{C}$ have a protective effect during but not immediately after hypoxia-ischemia. These findings have important implications about the thermoregulatory control of the sick newborn infant. (Pediatr Res 34: 525529, 1993)
\end{abstract}

It is well recognized that profound hypothermia (temperature $<30^{\circ} \mathrm{C}$ ) markedly reduces the brain damage associated with cardiac arrest, and for that reason is frequently used during the operative repair of congenital cardiac lesions $(1,2)$. More recently, several studies in adult animals have suggested that even mild reductions $\left(2\right.$ to $\left.6^{\circ} \mathrm{C}\right)$ of either brain or core temperature during reversible forebrain ischemia also significantly decrease the extent of neurologic injury (3-7). Moreover, postischemia there appears to be a "therapeutic window" of up to $30 \mathrm{~min}$ duration, during which time the introduction of mild hypother-

Received September 30, 1992: accepted May 14, 1993

Correspondence: Jerome Y. Yager, MD, Department of Pediatrics, Royal University Hospital, University of Saskatchewan. Saskatoon, Saskatchewan, Canada S7N $0 \times 0$.

Supported by grants from the National Institute of Child Health and Human Development HD 19913 (R.C.V.) and by a Medical Research Council of Canada Fellowship Award (J.Y.Y.). mia also is protective $(8,9)$. Conversely, hyperthermia either during or after an hypoxic-ischemic insult worsens ultimate brain damage $(10,11)$.

In contrast to the adult, the human term infant, under physiologic circumstances can maintain thermal neutrality only over a severely restricted range of environmental temperatures (1215). Infants, who are frequently exposed to a variety of "stresses" (birth asphyxia. hypoxia), are usually rendered incapable of even this restricted temperature control (heterothermia). Therefore, environments, which are by definition neutral, can be detrimental under some circumstances. Given the important role thermoregulation plays in the modern-day care of the sick newborn, the present set of experiments was designed to determine the effect of mild systemic hypothermia applied either during or after hypoxia-ischemia on perinatal brain damage.

\section{MATERIALS AND METHODS}

Pregnant Wistar rats, purchased from a local breeder, were individually housed and fed ad libitum. Rat pups, delivered vaginally, were suckled with their dams until the day of experimentation. The effect of mild hypothermia on brain injury was assessed either during or after cerebral hypoxia-ischemia at environmental temperatures of $37^{\circ} \mathrm{C}$ (control) and $34^{\circ} \mathrm{C}$ or $31^{\circ} \mathrm{C}$ (hypothermia).

\section{PRELIMINARY STUDIES}

Preliminary studies were performed to determine the relationship between brain and core (rectal) temperature when environmental temperatures were altered either during hypoxia-ischemia or recovery. Seven-d postnatal rat pups underwent permanent unilateral right common carotid artery ligation under halothane anesthesia (4\% induction; $1 \%$ maintenance). Neither common carotid artery ligation alone nor hypoxia alone causes a reduction in cerebral blood flow (16) or evidence of cellular injury to the ipsilateral hemisphere (17). Thermistor probes (model 511, Yellow Springs Instruments, Yellow Springs, $\mathrm{OH}$ ) measuring 0.024 inches in diameter were inserted into the brain to a depth of 2 $\mathrm{mm}$ through a burr hole positioned $1.5 \mathrm{~mm}$ to the right of the sagittal suture and $2 \mathrm{~mm}$ anterior to the lambdoid suture. The probe was then sutured firmly to the scalp, and care was taken to ensure that the skull was completely covered by resuturing the scalp flap in place. A second probe was then placed rectally to a depth of $0.5 \mathrm{~cm}$ and taped to the tail. The animals were gently swaddled to minimize movement and possible dislocation of the probes and were allowed to recover from anesthesia for 2 to $3 \mathrm{~h}$ under a warming lamp at nesting temperature. The total duration of surgery lasted no longer than $15 \mathrm{~min}$.

After recovery from surgery, the correlation between brain and core temperature during hypothermic hypoxia-ischemia was determined. Individual rat pups were placed in $500-\mathrm{mL}$ glass jars 
immersed in water baths held constant at either $31^{\circ} \mathrm{C}, 34^{\circ} \mathrm{C}$, or $37^{\circ} \mathrm{C} \pm 0.5^{\circ} \mathrm{C}$. The animals were allowed to equilibrate with the environment for $30 \mathrm{~min}$, after which hypoxia was induced by venting $8 \% \quad \mathrm{O}_{2}$-balance nitrogen through inlet/outlet portals. After $3 \mathrm{~h}$ of hypoxia-ischemia, the rat pups were recovered in the water baths for an additional $3 \mathrm{~h}$ at the preset temperature of either $37^{\circ} \mathrm{C}, 34^{\circ} \mathrm{C}$, or $31^{\circ} \mathrm{C}$.

The relation between brain and core temperature during postischemic hypothermia was assessed by exposing recovered carotid-artery ligated rat pups to hypoxia $\left(8 \% \mathrm{O}_{2}\right.$-balance nitrogen) for $3 \mathrm{~h}$ at a constant temperature of $37 \pm 0.5^{\circ} \mathrm{C}$, after which the animals were placed in water baths set at either $37^{\circ} \mathrm{C}, 34^{\circ} \mathrm{C}$, or $31^{\circ} \mathrm{C}$ for an additional $3 \mathrm{~h}$.

During all preliminary studies, brain and core temperatures were recorded from each animal: 1) after stabilization during normoxia, 2) every $15 \mathrm{~min}$ during hypoxia-ischemia and the immediate recovery period $(30 \mathrm{~min})$, and 3 ) every $30 \mathrm{~min}$ thereafter for up to $3 \mathrm{~h}$.

After the experimental procedure, all rat pups were killed and cerebral thermistor probe placement confirmed by direct visualization of the probe after coronally sectioning the fresh brain. Data from only those animals that survived and in which the probe placement was within the caudate-putamen were considered valid. The information obtained from these preliminary studies then was used in the design of the definitive experimental protocol.

\section{EXPERIMENTAL PROTOCOL}

Intra- and posthypoxic-ischemic hypothermia. To determine the consequence of mild hypothermia on neuropathologic outcome during or after hypoxia-ischemia, separate groups of 7-dpostnatal rat pups underwent right common carotid artery ligation with rectal probe placement as described above (probes were not inserted into the brain). The animals then, were allowed to recover under a warming lamp set at nesting temperature $(34.5$ $\pm 0.5^{\circ} \mathrm{C}$ ) for 2 to $3 \mathrm{~h}$, after which they were placed in the 500 $\mathrm{mL}$ jars and exposed to hypoxia ( $8 \%$ oxygen - balance nitrogen) at either $37^{\circ} \mathrm{C}, 34^{\circ} \mathrm{C}$, or $31^{\circ} \mathrm{C}$ for $3 \mathrm{~h}$. The rectal probes were then removed, and the pups were returned to their dams and allowed to grow to $30 \mathrm{~d}$ postnatal age, at which time they were killed for neuropathologic assessment.

In experiments to determine the effect of postischemic hypothermia, 7-d-postnatal rat pups were prepared surgically as described above and exposed to hypoxia at $37^{\circ} \mathrm{C}$ for $3 \mathrm{~h}$. Immediately after the insult, the pups were recovered in water baths preset at temperatures of $37^{\circ} \mathrm{C}, 34^{\circ} \mathrm{C}$, or $31^{\circ} \mathrm{C}$ in room air for 3 $\mathrm{h}$ of recovery. All animals were then returned to their dams to $30 \mathrm{~d}$ of age for subsequent neuropathologic assessment.

Neuropathologic assessment. Brain damage was examined at $30 \mathrm{~d}$ postnatal age ( $23 \mathrm{~d}$ of recovery). The present model provides for a spectrum of cerebral injury ranging from normal to severe brain infarction ipsilateral to the common carotid artery ligation (17). To accurately assess and compare the extent of brain damage, a system of neuropathologic rank scoring was used (18).

Each rat pup was given a lethal injection of pentobarbital $(100$ $\mathrm{mg} / \mathrm{kg}$ ) intraperitoneally, after which its brain was rapidly removed from its skull and immersed in solutions of formaldehyde, acetic acid, and methanol (1:1:8). Individual rat brains then were examined by two independent observers blinded to the treatment category. Visual inspection of the brains displayed a range of damage from 1 ) normal-appearing brains in which no discernable difference in the size of the two cerebral hemispheres was noted; 2) mild damage in which the lateral-posterior aspect of the right hemisphere was atrophic; 3 ) moderate damage indicating brains in which both the anterior and posterior aspects of the right hemisphere were atrophic; and 4) severe damage referring to the total destruction, by prior infarction, of the cerebral cortex in the distribution of the middle cerebral artery of the ipsilateral hemisphere. The observers then graded the extent of damage in each animal by rank scoring each brain from least to most damaged. Each brain was compared with the entire group and ranked accordingly.

All brains in the intraischemic groups were further assessed histopathologically. Cerebri were sectioned at the level of the anterior commissure and posteriorally through the mammillary bodies. Sections were stained with hematoxylin and eosin, and examined histologically. Brains with mild damage were noted to have evidence of selective neuronal necrosis. Infarcted brains displayed pan-necrosis of all tissue elements with cystic infarction. Histologic sections from each animal were compared and again rank ordered from least to most damaged.

Statistical analysis. Comparisons of core and brain temperature were made by linear regression analysis. Rank scoring of data for assessment of neuropathologic outcome were obtained nonparametrically using the Mann-Whitney $U$ test. Analysis of variance with Dunnett's correction was applied where appropriate. Significance was considered at $p<0.05$.

\section{RESULTS}

Preliminary studies. Seven-d postnatal rats displayed partial homeothermic control under normoxic environmental conditions. At an environmental temperature of $37 \pm 0.5^{\circ} \mathrm{C}$, the animals maintained their core temperatures at $36.6 \pm 0.6^{\circ} \mathrm{C}$, whereas at a temperature of $34^{\circ} \mathrm{C}$ or $31^{\circ} \mathrm{C}$, core temperatures were maintained at $34.8^{\circ} \mathrm{C}$ or $34.6^{\circ} \mathrm{C}$, respectively $(p<0.05$ compared with normothermia).

With the onset of hypoxia-ischemia, the temperature of all rat pups rapidly changed to reflect that of their environmental temperature (Fig. 1). During recovery from hypoxia-ischemia, two patterns of thermal regulation were evident. Rat pups exposed to hypoxia-ischemia at $34^{\circ} \mathrm{C}$ or $31^{\circ} \mathrm{C}$ (and therefore either not damaged, or only mildly damaged) (see below) reacquired their ability to thermoregulate almost immediately on recovery from hypoxia-ischemia (Fig. 1), their core/brain temperatures returning to values more closely reflecting that of their preischemic interval. In contrast, those animals exposed to hypoxiaischemia at $37^{\circ} \mathrm{C}$, (rat pups that uniformly displayed severe damage) and who were placed in cooler temperatures postischemically did not return to their preischemic homeothermic state, but rather their core temperatures continued to closely reflect that of the environment indicating a poikilothermic state (Fig. 2).

Brain and core temperatures correlated well during both normoxia and hypoxia-ischemia (Figs. 1 and 2$)[r=0.75,0.62$, and 0.66 for $37^{\circ} \mathrm{C}, 34^{\circ} \mathrm{C}$, and $31^{\circ} \mathrm{C}$ groups, respectively, $\left.(p<0.05)\right]$. During recovery, the correlation between brain and core temperatures persisted only in those pups exposed to hypoxia-ischemia at $37^{\circ} \mathrm{C}$ and were recovered at either $31^{\circ} \mathrm{C}(r=0.85 ; p<0.01)$.

Intraobserver agreement for visual inspection of the gross neuropathologic injury was very high $(r>0.95)$. Further, there was excellent agreement about the extent of brain damage between cerebral cortices examined visually and histologically $(r>0.95)$.

Mortality and neuropathologic outcome. There were no deaths in either group exposed to hypoxia-ischemia at $34^{\circ} \mathrm{C}$ or $31^{\circ} \mathrm{C}$ compared with a $10 \%$ mortality during hypoxia-ischemia at $37^{\circ} \mathrm{C}$.

Brain damage occurred in $90 \%$ of those rat pups exposed to hypoxia-ischemia at $37^{\circ} \mathrm{C}, 70 \%$ of which displayed cerebral infarcts by histologic examination (Fig. 3).

To determine whether small variations in temperature were associated with the variability in brain damage seen in this model of perinatal hypoxia-ischemia, mean individual core temperatures of the animals exposed to hypoxia-ischemia at $37^{\circ} \mathrm{C}$ were compared with their neuropathologic mean rank score. Minor fluctuations around $37^{\circ} \mathrm{C}\left( \pm 0.5^{\circ} \mathrm{C}\right)$ in brain or rectal temperatures did not correlate with the extent of brain damage in this group of animals. Cerebral injury decreased significantly between each 

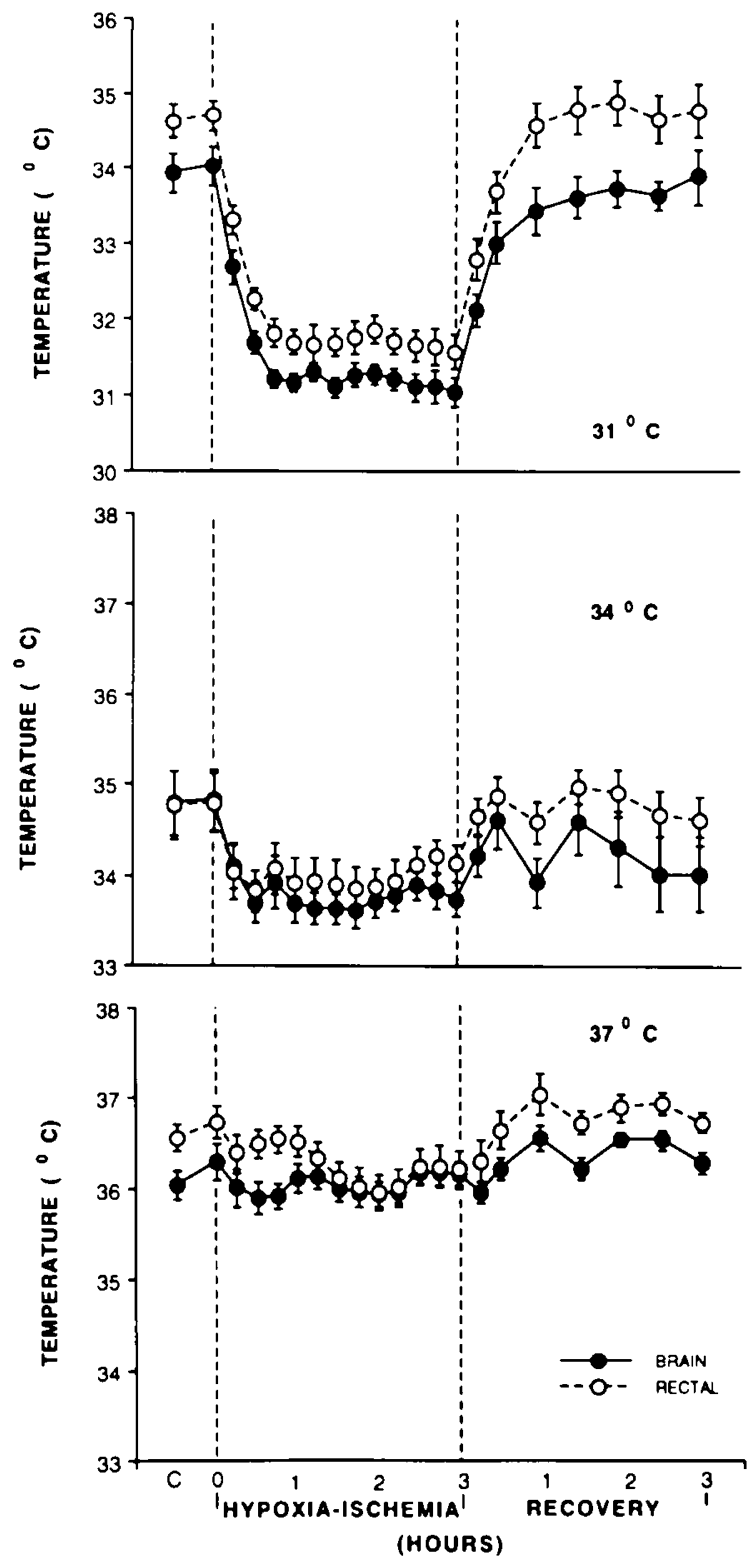

Fig. 1. Brain and core temperature during normoxia, hypoxia-ischemia, and recovery all at either $37^{\circ} \mathrm{C}, 34^{\circ} \mathrm{C}$, or $31^{\circ} \mathrm{C}$. Values are the means \pm SEM of six to eight animals in each group.

group $(p<0.01)$. At intraischemic temperatures of $34^{\circ} \mathrm{C}, 30 \%$ (6 of 21) of the animals displayed neuronal injury, and only one exhibited mild infarction. None of the animals exposed to hypoxia-ischemia at $31^{\circ} \mathrm{C}$ displayed brain damage.

There was no difference in the extent of brain injury among the groups of rat pups exposed to hypoxia-ischemia at $37^{\circ} \mathrm{C}$ and recovered at either $37^{\circ} \mathrm{C}, 34^{\circ} \mathrm{C}$, or $31^{\circ} \mathrm{C}(p>0.75)$ (Fig. 4$)$. Therefore, hypothermia induced immediately after hypoxia-ischemia at $37^{\circ} \mathrm{C}$ provided no cerebral protection.

\section{DISCUSSION}

The findings of the present study provide insight into the extent to which 1 ) the thermoregulatory capability of the immature rat is compromised by hypoxic-ischemic brain injury, and 2) mild hypothermia protects the immature brain during the evolution of hypoxic-ischemic damage.

Our results extend those of Young et al. (19), who demonstrated that reducing ambient temperature to $29^{\circ} \mathrm{C}$ and $21^{\circ} \mathrm{C}$ partially and completely protects the immature rat brain from cerebral hypoxic-ischemic damage, respectively. Under the pres-

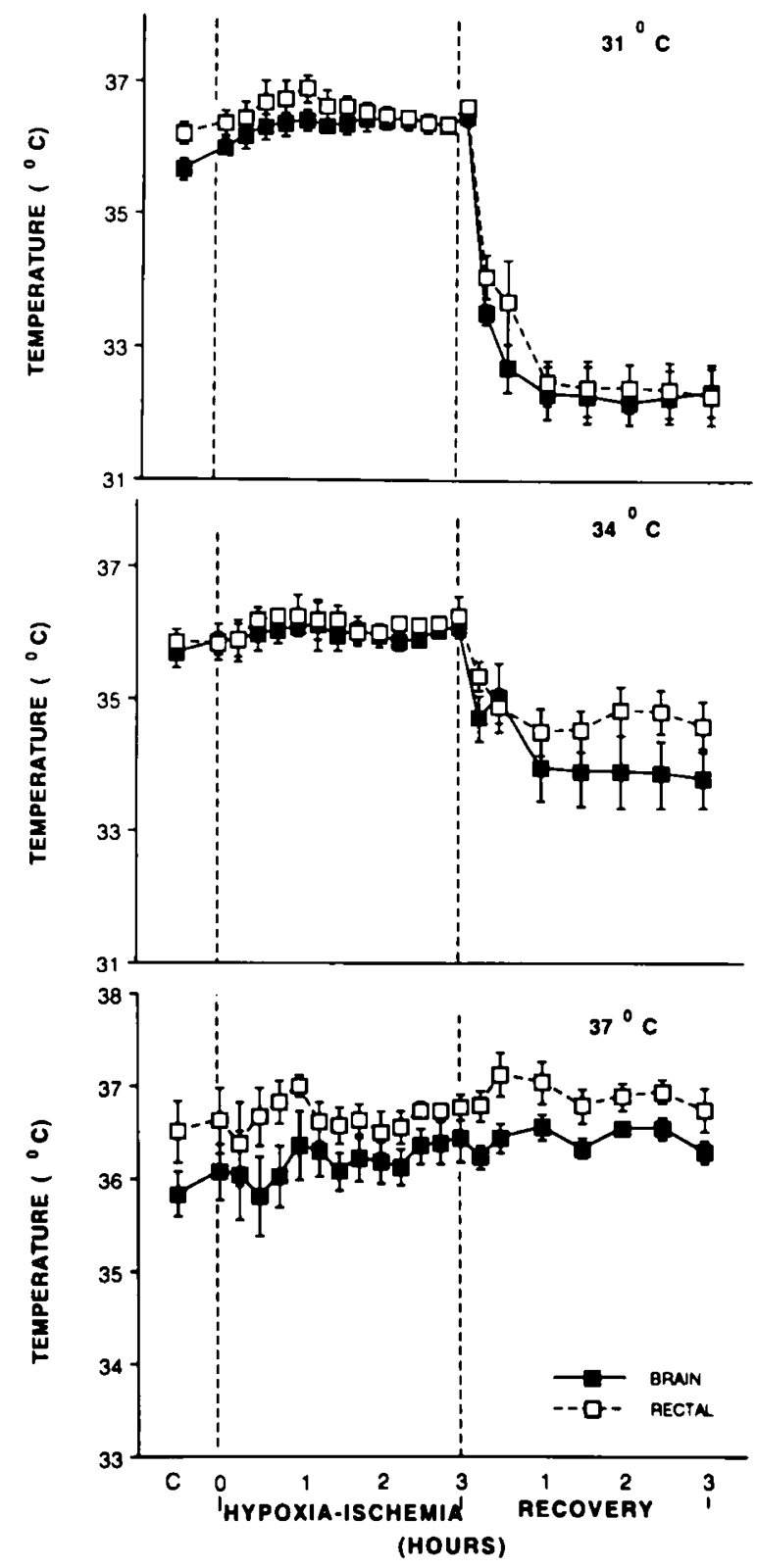

Fig. 2. Brain and core temperature during normoxia and hypoxiaischemia at $37^{\circ} \mathrm{C}$ and during recovery at either $37^{\circ} \mathrm{C}, 34^{\circ} \mathrm{C}$. or $31^{\circ} \mathrm{C}$. Values are the means \pm SEM of six to eight animals in each group.

ent conditions, reductions in body temperature during hypoxiaischemia by as little as $3^{\circ} \mathrm{C}$ or $6^{\circ} \mathrm{C}$ produced near-complete and complete brain protection. Similar results have been obtained in adult animals whereby either mild systemic or selective brain cooling during global or focal cerebral ischemia is protective ( 3 , $5,6,19)$.

In adult animal models of cerebral ischemia, postischemic induction of moderate hypothermia also has been shown to ameliorate brain damage. A reduction in brain temperature from $36^{\circ} \mathrm{C}$ to $30^{\circ} \mathrm{C}$ within $30 \mathrm{~min}$ after bihemispheric cerebral ischemia significantly reduced the pyramidal neuron damage of the $\mathrm{CA}_{1}$ sector of the hippocampus. Beneficial effects are no longer present when moderate hypothermia is delayed beyond $30 \mathrm{~min}$ of recovery $(8,20)$. Similar cerebral protective effects have been shown after total cerebral ischemia produced by cardiac arrest and even after experimental traumatic brain injury $(21,22)$. In contrast, postischemic hypothermia induced immediately after the insult in our immature rat model of cerebral hypoxia-ischemia provided no benefit to the developing brain.

The mechanism by which intraischemic hypothermia exerts 


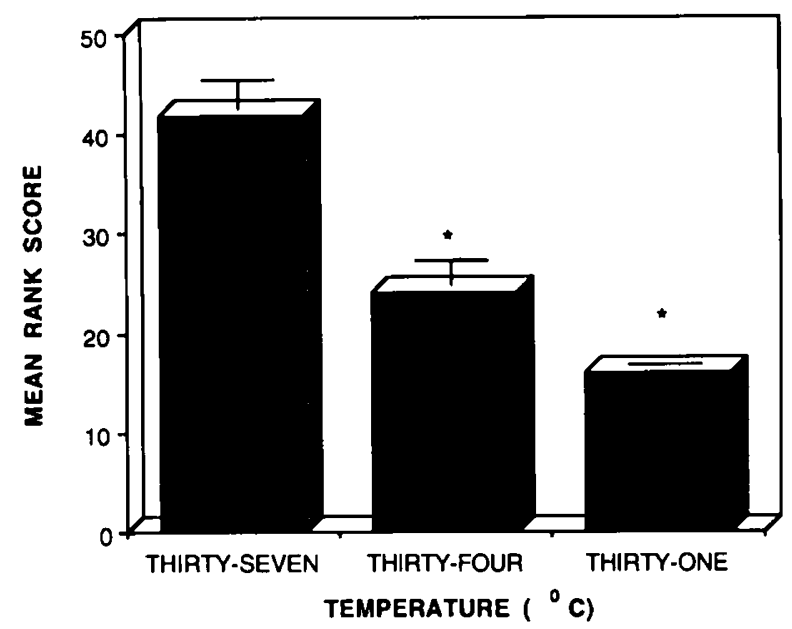

Fig. 3. Mean rank score of brains of rat pups exposed to intraischemic hypothermic hypoxia-ischemia at $37^{\circ} \mathrm{C}(n=16), 34^{\circ} \mathrm{C}(n=21)$, and $31^{\circ} \mathrm{C}(n=16)$. The mean score of brains assessed as being normal was 16 , with values $>16$ having evidence of cerebral damage. Values represent \pm SEM. ${ }^{*}, p<0.01$ compared with controls at $37^{\circ} \mathrm{C}$.

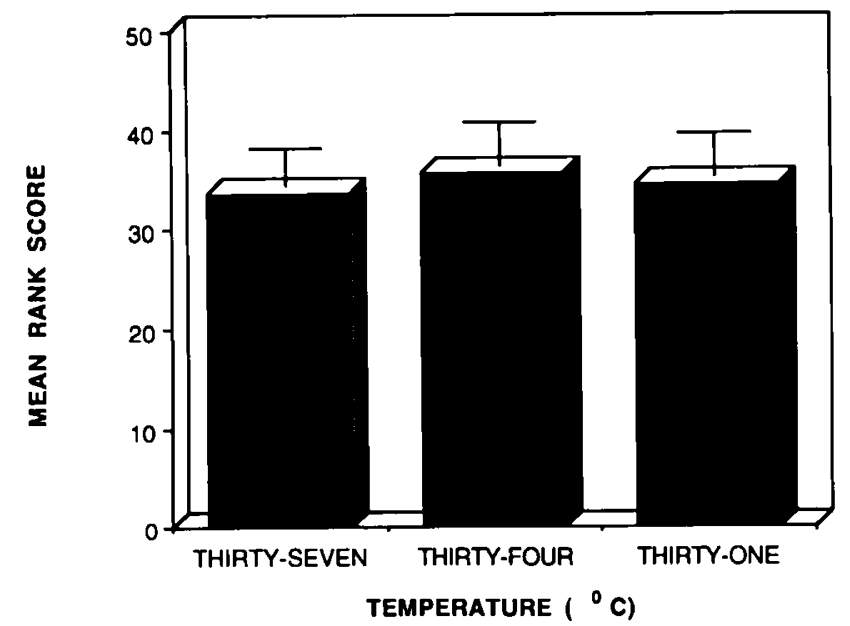

Fig. 4. Mean rank score of brains of rat pups exposed to hypoxiaischemia at $37^{\circ} \mathrm{C}$, followed by the induction of either normothermia $\left(37^{\circ} \mathrm{C}, n=22\right)$ or mild hypothermia $\left(34^{\circ} \mathrm{C}, n=20\right.$ or $\left.31^{\circ} \mathrm{C}, n=26\right)$ during recovery for $3 \mathrm{~h}$. Values represent means \pm SEM.

its protective effect remains unknown. Several investigators have implicated a role for hypothermia in attenuating excitatory amino acid (glutamate, aspartate) neurotoxicity during hypoxiaischemia $(23,24)$ and in the prolongation of the extracellular accumulation of the inhibitory, neurotransmitter glycine (23, 25). Whether a similar mechanism for the protective effect of hypothermia is at play in the immature brain remains in question. Few studies have documented an increase in glutamate afflux from the axon terminal into the extracellular space during hypoxia-ischemia in the developing brain. Gordon et al. (26) found only a variable 3 -fold elevation of extracellular glutamate and aspartate during hypoxia-ischemia in the 7-d-old rat compared with the greater than 60 -fold increase generally seen in adult brain undergoing ischemic stress (27). Under simulated ischemic conditions, Cherici et al. (28) were unable to document an increase in glutamate or aspartate release from prepared immature rat hippocampal slices compared with a dramatically enhanced release of these neurotransmitters from similarly prepared adult hippocampal slices.

The complete absence of a protective effect of mild hypothermia after hypoxia-ischemia was an unexpected finding. In our study, core/brain temperatures began to fall within minutes of the onset of the recovery period. By 15 min postischemia, brain temperature had reduced by $1.3^{\circ} \mathrm{C}$ and $3.0^{\circ} \mathrm{C}$ in the $34^{\circ} \mathrm{C}$ and $31^{\circ} \mathrm{C}$ hypothermic groups, respectively. Though it is possible that a more rapid reduction in brain temperature may have provided some protection, the absolute lack of any difference in outcome among the three groups clearly makes this unlikely.

In adult animals, monitoring of core and brain temperature has shown that a transient hyperthermia (approximately $1.0^{\circ} \mathrm{C}$ ) occurs postischemia $(9,29)$. Thus, it has been postulated that maintaining body and brain normothermic or inducing mild hypothermia during early recovery can partially protect the previously ischemic brain from damage by inhibiting the postischemic rise in temperature $(8,9)$. In the present study, an elevation above normal of either core or brain temperature did not occur during recovery. Whichever accompanying pathophysiologic alterations occur during the period of postischemic hyperthermia in the adult, therefore, clearly do not play a role in the immature rat during recovery.

The effect of mild hypothermia in reducing the cerebral metabolic rate during hypoxia-ischemia and recovery and its role in cerebral protection remain controversial. Contrasting data from experiments performed in adult animals show a sparing of high energy phosphate depletion during hypothermic ischemia on the one hand $(7,30,31)$ but an inability to preserve optimal cellular ATP on the other $(3,32)$. The effect of mild hypothermia on energy metabolism of the immature brain during hypoxia-ischemia remains unknown.

On recirculation after hypoxia-ischemia, only a partial recovery of cerebral high-energy phosphate reserves occurs in the 7-dold rat (33), whereas in the adult brain rendered ischemic there is an initial complete restoration of energy reserves followed by a secondary decline (34-36). This early replenishment of ATP presumably is required for the reestablishment of membrane potentials necessary for the survival of those neurons and glia adversely affected during the ischemic phase but that have the potential to recover (37). Given that a reduction in temperature of even a few degrees inhibits cerebral metabolic rate (38), the lack of protection afforded by posthypoxic-ischemic hypothermia in our study might be due to an inability of ATP to recover. Without an immediate restitution of energy stores and a chance for restabilization of cell membranes, those cells potentially recoverable will die.

The findings of the present animal investigation may have important implications about the human situation. In the newborn human infant, earlier studies pertaining to the effect of environmental temperature on outcome suggested that infants maintained in a warm environment displayed a reduced mortality compared with those maintained at cooler temperatures (3942). As a result, current practice emphasizes the maintenance of thermoneutrality in the management of the sick human newborn infant. Whereas prolonged hypothermia has obvious detrimental effects $(22,43-45)$, maintenance of neutral temperatures, irrespective of the condition of the newborn infant, may be harmful. Given the present experimental findings, circumstances appear to exist in which the judicial intermittent use of mild hypothermia might improve neurologic morbidity of the compromised newborn infant. Additional studies are required to more specifically delineate this potential therapeutic intervention.

\section{REFERENCES}

1. Hickey PR. Anderson NP 1987 Deep hypothermic circulatory arrest: a review of pathophysiology and clinical experience as a basis for anesthetic management. J Cardiothorac Anes 1:137-155

2. Kirklin J, Kirklin J, Pacifco A 1985 Deep hypothermia and total circulatory arrest. In: Arciniegas E (ed) Pediatric Cardiac Surgery. Year Book Medical Publishers, Inc, Chicago, pp 79-85

3. Busto R, Dietrich WD, Globus MY-T, Valdes I, Schenberg P. Ginsberg MD 1987 Small differences in intraischemic brain temperature critically determine the extent of ischemic neuronal injury. J Cereb Blood Flow Metab 7:729-738

4. Busto R, Dietrich D, Globus MY-T, Ginsberg MD 1989 The importance of brain temperature in cerebral ischemic injury. Stroke 20:1113-1114 
5. Green EJ. Dietrich WD, Dijk FV, Busto R, Markgraf CG, McCabe PM, Ginsberg MD, Schneiderman N 1992 Protective effects of brain hypothermia on behaviour and histopathology following global cerebral ischemia in rats. Brain Res 580:197-204

6. Ridenour TR, Warner DS. Todd MM, McAllister AC 1992 Mild hypothermia reduces infarct size resulting from temporary but not permanent focal ischemia in rats. Stroke 23:733-738

7. Welsh FA, Sims RE, Harris VA 1990 Mild hypothermia prevents ischemic injury in gerbil hippocampus. J Cereb Blood Flow Metab 10:557-563

8. Busto R, Dietrich WD. Globus MY-T, Ginsberg MD 1989 Post-ischemic moderate hypothermia inhibits CAI hippocampal ischemic neuronal injury. Neurosci Lett 101:299-304

9. Kuroiwa T, Bonnkoh P, Hossmann K-A 1990 Prevention of post-ischemic hyperthermia prevents ischemic injury of $\mathrm{CA}$, neurons in gerbils. $\mathrm{J}$ Cereb Blood Flow Metab 10:550-556

10. Dietrich WD, Busto R, Valdes I, Loor Y 1990 Effects of normothermic versus mild hyperthermic forebrain ischemia in rats. Stroke 21:1318-1325

11. Minamisawa H, Smith ML, Siesjo BK 1990 The effect of mild hyperthermia and hypothermia on brain damage following 5,10 and 15 minutes of forebrain ischemia. Ann Neurol 28:26-33

12. Alexander G 1975 Body temperature in mammalian young. Br Med Bull 31:62-68

13. Bruck K 1961 Temperature regulation in the newborn infant. Biol Neonate 3:65-119

14. Hey EN, Scopes JW 1987 Thermoregulation in the newborn: In: Avery GB (ed) Neonatology, Pathophysiology and Management of the Newborn. JB Lippincott Co, Philadelphia, pp 201-211

15. Hull D 1988 Thermal control in very immature infants. Br Med Bull 44:971983

16. Vannucci RC, Lyons DT, Vasta F 1988 Regional cerebral blood flow during hypoxia-ischemia in immature rats. Stroke 19:245-250

17. Rice JE, Vannucci RC, Brierley JB 1981 The influence of immaturity on hypoxic-ischemic brain damage in the rat. Ann Neurol 9:131-141

18. Yager JY, Heitjan DF, Towfighi J, Vannucci RC 1992 Effect of insulin induced and fasting hypoglycemia on perinatal hypoxic-ischemic brain damage. Pediatr Res 31:138-142

19. Young RSK. Olenginski TP, Yagel SK. Towfighi J 1983 The effect of graded hypothermia on hypoxic-ischemic brain damage: a neuropathologic study in the neonatal rat. Stroke $14: 929-934$

20. Moller FB, Smith M-L. Siesjo BK 1989 Effects of hypothermia on brain ischemia: a comparison of intraischemic and postischemic hypothermia. $\mathrm{J}$ Cereb Blood Flow Metab 9:S276(abstr)

21. Clifton GL, Jiang JY, Lyeth BG, Jenkins LW, Hamm RJ, Hayes RL 1991 Marked protection by moderate hypothermia after experimental traumatic brain injury. J Cereb Blood Flow Metab 11:114-121

22. Leonov Y, Sterz F, Safar P, Radovsky A 1990 Moderate hypothermia after cardiac arrest of 17 minutes in dogs. Stroke 21:1600-1606

23. Baker AJ, Zornow MH, Grafe MR. Schiller MS, Skilling SR, Smullin DH, Larson AA 1991 Hypothermia prevents ischemia-induced increases in hippocampal glycine concentrations in rabbits. Stroke 22:666-673

24. Busto R, Globus MY-T, Dietrich D, Martinez E, Valdes I, Ginsberg MD 1989 Effect of mild hypothermia on ischemia-induced release of neurotransmitters and free fatty acids in rat brain. Stroke 20:904-910

25. Simpson RE, Walter GA, Phillis JW 1990 The effects of hypothermia on amino acid neurotransmitter release from the cerebral cortex. Neurosci Lett 124:83-86

26. Gordon KE, Simpson J, Statman D. Silverstein FS 1991 Effects of perinatal stroke on striatal amino acid efflux in rats studied with in vivo microdialysis. Stroke 22:928-932

27. Hillered L. Hallstrom A. Segersvard S. Persson L. Ungerstedt U 1989 Dynamics of extracellular metabolites in the striatum after middle cerebral artery occlusion in the rat monitored by intracerebral microdialysis. J Cereb Blood Flow Metab 52:1823-1829

28. Cherici G, Alesiani M, Pellegrini-Giampietro DE, Moroni F 1991 Ischemia does not induce the release of excitotoxic amino acids from the hippocampus of newborn rats. Dev Brain Res 60:235-240

29. Kato H. Araki T. Kogure K 1991 Postischemic spontaneous hyperthermia is not a major aggravating factor for neuronal damage following repeated brief cerebral ischemia in the gerbil. Neurosci Lett 126:21-24

30. Berntman L, Welsh FA. Harp JR 1981 Cerebral protective effect of low-grade hypothermia. Anesthesiology 55:495-498

31. Johnson DC, Nishimura M, Okunieff P, Kazemi H, Hitzig B 1989 Effects of hypothermia on rat brain $\mathrm{pHi}$ and phosphate metabolite regulation by ${ }^{31} \mathrm{P}$ NMR. J Appl Physiol 67:2527-2534

32. Chopp M, Knight R. Tidwell CD, Helpern JA. Brown E, Welch KMA 1989 The metabolic effects of mild hypothermia on global cerebral ischemia and recirculation in the cat: comparison to normothermia and hyperthermia. $J$ Cereb Blood Flow Metab 9:141-148

33. Yager JY, Brucklacher RM, Vannucci RC 1992 Cerebral energy metabolism during hypoxia-ischemia and early recovery in immature rats. Am J Physiol 262:H672-H677

34. Munekata K, K-A Hossmann 1987 Effect of five-minute ischemia on regional $\mathrm{pH}$ and energy state of the gerbil brain: relation to selective vulnerability of the hippocampus. Stroke 18:412-417

35. Pettigrew LC, Grotta JC, Rhoades HM, Reid C, McCandless DW 1988 Regional depletion of adenosine triphosphate, phosphocreatine and glucose in ischemic hippocampus. Metabol Brain Dis 3:185-198

36. Selman WR, Ricci AJ, Crumrine RC, LaManna JC. Ratcheson RA, Lust WD 1990 The evolution of focal ischemic damage: a metabolic analysis. Metabol Brain Dis 5:33-44

37. Kogure K. Tanaka T, Araki T 1988 The mechanism of ischemic-induced brain cell injury. Neurochem Pathol 9:145-170

38. Siesjo BK 1978 Brain Energy Metabolism. Wiley, Chichester, England

39. Buetow KC, Klein SW 1964 Effect of maintenance of normal skin temperature on survival of infants of low birthweight. Pediatrics 34:163-170

40. Jolly H, Molyneux P. Newell DJ 1962 A controlled study of the effect of temperature on premature babies. J Pediatr 60:889-894

41. Silverman WA, Fertig JW, Berger PA 1958 The influence of the thermal environment upon the survival of newly born premature infants. Pediatrics 31:876-885

42. Day RL, Caliguiri L, Kamenski C, Ehrlich F 1964 Body temperature and survival of premature infants. Pediatrics 34:171-181

43. Greene PS. Cameron DE. Mohlala ML. Dinatale JM, Gardner TJ 1989 Systolic and diastolic left ventricular dysfunction due to mild hypothermia. Circulation (suppl III) 80:44-48

44. Reed RL. Bracey AW. Hudson JD, Miller TA. Fischer RP 1990 Hypothermia and blood coagulation: dissociation between enzyme activity and clotting factor levels. Circ Shock 32:141-152

45. Steen PA, Soule EH. Michenfelder JD 1979 Detrimental effect of prolonged hypothermia in cats and monkeys with and without regional cerebral ischemia. Stroke 10:522-529 